\title{
Key elements of an entrepreneurial (business) model in the biogas sector. Insights from Romania
}

\author{
Roxana CLODNIȚCHI \\ The Bucharest University of Economic Studies, Faculty of Business Administration in Foreign \\ Languages, Bucharest, Romania \\ roxana.clodnitchi@fabiz.ase.ro \\ Alexandra Cătălina NEDELCU \\ The Bucharest University of Economic Studies, Faculty of Business Administration in Foreign \\ Languages, Bucharest, Romania \\ catalina.nedelcu@fabiz.ase.ro
}

\begin{abstract}
The current volatile economic environment and the evermore shorter technology cycles impact the way business is done today, especially in an emerging field like the renewable energy sector. Business modelling proves itself as an instrument, which may impact decisively the success or failure of a business. The aim of this article is to identify and present the key elements defining entrepreneurial models in the renewable energy field, as resulted from a synthesis of the recent literature available in journals indexed in international databases of mainstream publications about business models and entrepreneurial models as well as from empirical research performed in the past five years. The research result consists in a systematisation on past approaches on business modelling and the development and adaptation of the entrepreneurial model's definition specific for the biogas sector.
\end{abstract}

Keywords: renewable energy, biogas, business modelling, entrepreneurial models, Romania.

\section{Introduction}

Nowadays, we are facing more and more interest for renewable energy, as the European Commission (2009) set out the need to reduce greenhouse gas emissions and to strengthen the security of energy supply. In this context, we are facing an increasing interest in biogas technology, which can be used to produce heat or electricity. According to Ericsson et al. (2013) (as cited by Karlsson et al., 2018), the biogas technology represents also a way to meet social and environmental responsibilities, as well as to increase resource efficiency in industrial sectors.

However, biogas producers are facing numerous barriers in terms of production, distribution, or marketing (Martin, 2015). As presented by Karlsson et al. (2018), the studies conducted in order to address these barriers emphasize the importance of policy making in the biogas production (Larsson et al., 2013; Wilkinson, 2011; Smyth et al., 2010; Lantz et al., 2007;). Authors also identified a lack of simple and linear innovation processes for biogas systems (Lybæk et al., 2013; Sanden and Hillman, 2011; Raven and Geels, 2010;) and that a greater integration of actors into systems or networks is needed (Negro et al., 2007; Negro and Hekkert, 2008; Vernay et al., 2013).

As concluded by Karlsson et al. (2017), in order to strengthen and support the biogas sector we have to determine the real contribution of biogas producers, the way they should get paid and the quantification and valuation of their benefits in terms of 
sustainability. Therefore, it becomes more necessarily to determine a performant business model for these energy producers.

Regarding the business models, a more extensive overview on the scientific literature was published by Clodnitchi in two past papers (2017a, 2017b). We have seen that the subject of business models in the renewable and biogas sector is treated by a relatively small number of authors while the problem of entrepreneurial models in this ever growing sector at national and world level, has not been addressed yet, in articles indexed in international databases.

In this article, we aim to adapt the entrepreneurial model identified in previous research efforts to the specifics of the biogas sector and to facilitate its replication.

In order to test the Hypothesis "The Renewable Energy Sector implies distinctive key features of the entrepreneurial model from those specific to other sectors", we relied on a group study based on the Delphi method performed 2013-2015 by the research group Tanțău, Clodnițchi and Nichifor (Maassen).

The supposed abundance of natural resources, the existence of an attractive support system for the production of biogas energy, next to Romania's tradition in this field have not led to a sustained pace of development of the sector. The total biogas based capacity installed in power plants connected to the electric power grid in 2017 was only 18 MWel (Transelectrica, 2018).

We believe that this development is due to the entrepreneurial models implemented so far in this sector in Romania, so we propose to verify the hypothesis "The models currently implemented in the Romanian biogas sector are not fully adequate to the specific conditions of the Romanian business environment" by comparing the models implemented in biogas sector with anticipated models to be implemented in the future. This will result in the development of an advanced entrepreneurial model that can be applied in the biogas sector.

\section{Research methodology}

Our scientific approach started from the business model described by Osterwalder and Pigneur (2010), expanded with several other elements identified in theory. To achieve a clear overview on the theoretical framework concerning "business models", "entrepreneurial models" and their components, the authors performed an extensive research identifying the most relevant scientific references dealing with the subject, as presented by Clodnițchi (2017a, 2017b).

In order to develop an entrepreneurial model specific to the renewable energy sector in Romania, the authors conducted a series of unstructured interviews with business representatives. Therefore, they elaborated an extensive questionnaire on current and future business models which was applied in two stages, to a group of 26 experts with competencies in the renewable energy field, using the Delphi method.

\section{Business models in biogas - findings}

To analyse the development of a specific entrepreneurial model of the renewable energy sector, we started from three basic activities identified in the business model of most of the 
energy sector operators with whom we interacted. Figure 1 shows the core activities of a renewable energy operator

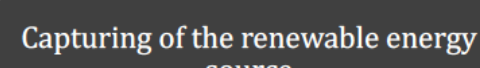
source
Transformation of the primary source into a energy vector of interest
Capitalisation of the obtained product

Figure 1. Business model of a plant operator on the basis of renewable energy. Key activities

Source: own illustration.

Based on the options expressed by the market participants in the open interviews, we have structured the identified components of the entrepreneurial models described by companies involved in renewable energy. For the biogas sector, we developed a classification depending on the key resource - the organic mass (substrate) underlying the fermentation process, presented in Fig. 2.

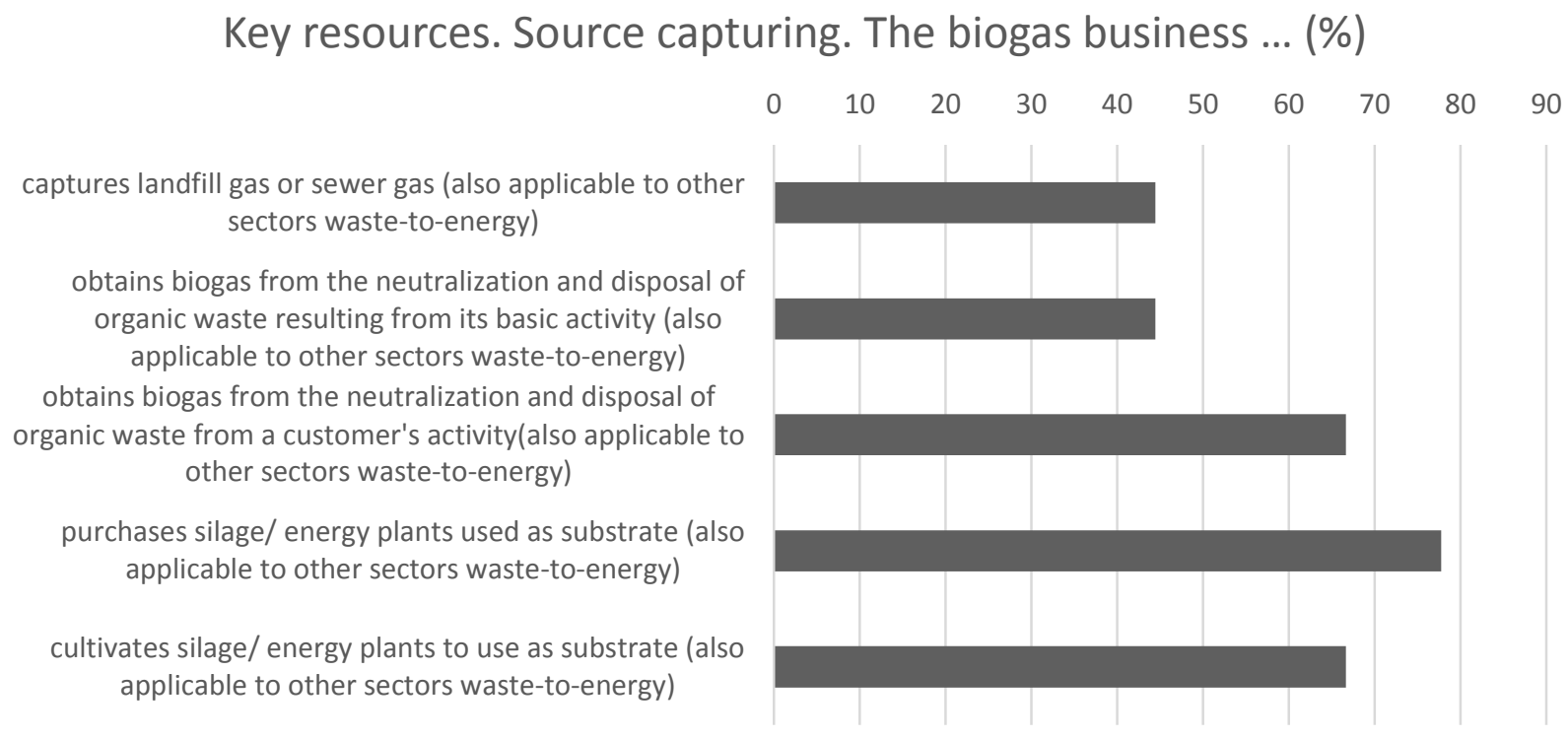

Figure 2. Fundamental characteristics of business models in the biogas sector - key resources

Source: own compilation based on results from study performed by Tanțău, Clodnițchi \& Nichifor (Maassen), 2013-2015, partially presented by Nichifor (2015).

If we turn our attention to the key activity - "transformation of the energy vector", the most common model applied is its transformation into electric power, as reflected in Fig. 3. 
Key Activities. Energy transformation. The biogas business ... (\%)

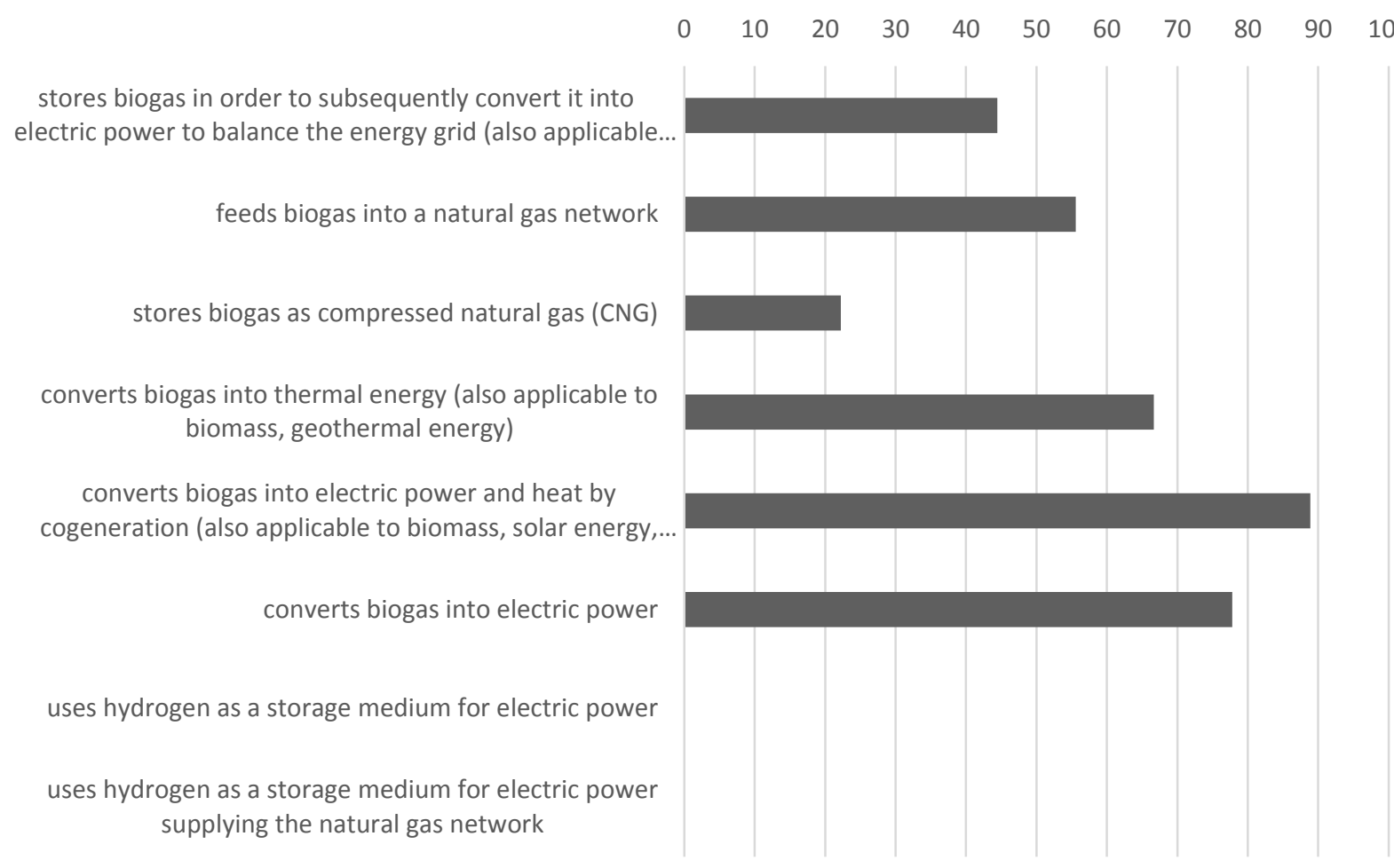

PICBE | 212

\section{Figure 3. Fundamental characteristics of business models in the biogas sector - key activities}

Source: ibid.

If we evaluate the revenue streams - the ways of capitalizing the obtained energy product, support schemes play an important role. The operator who converts the renewable energy source into electric power or electric and thermal energy through cogeneration and supplies the regional or national electric power grid with power could qualify until recently for a support scheme in Romania.

Most European countries have opted for a feed-in-tariff; in Romania, on the other hand, a system based on minimum quotas and green certificates was in place until 2016. The results of the analysis of the business models implemented in terms of energy recovery and other benefits obtained are presented in Fig. 2, 3 and 4. 


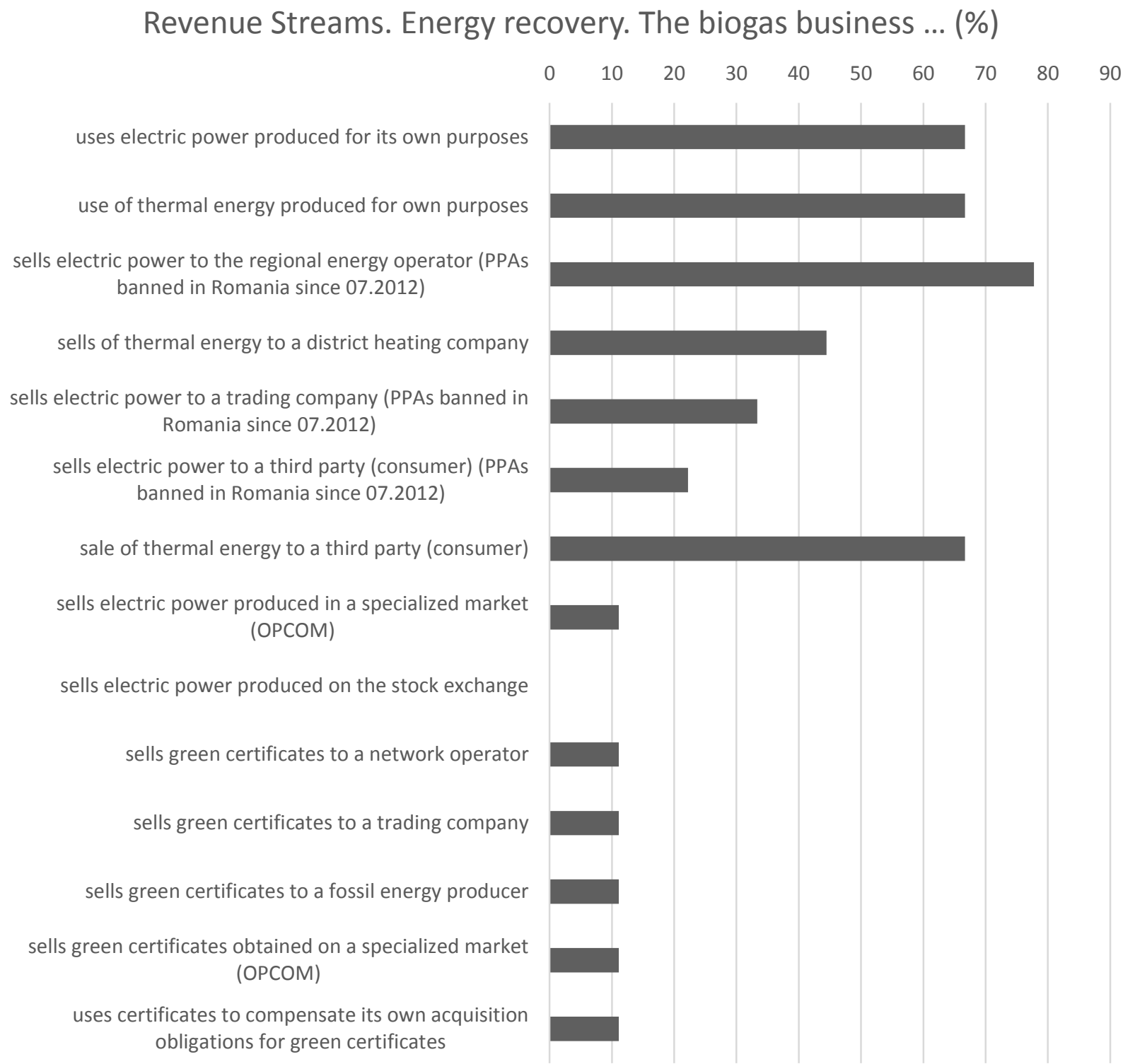

PICBE $\mid 213$

\section{Figure 4. Fundamental characteristics of business models in the biogas sector - Revenue streams}

Source: ibid.

Regarding the revenue streams, almost all companies had multiple responses, being involved in several different projects. Figure 5 presents the viable options for entrepreneurial models in the biogas field, based on the study conducted in 2013-2015. 


\begin{tabular}{|c|c|c|}
\hline $\begin{array}{c}\text { Capturing of the renewable energy } \\
\text { source }\end{array}$ & $\begin{array}{c}\text { Transformation of the primary } \\
\text { source into a energy vector of } \\
\text { interest }\end{array}$ & $\begin{array}{l}\text { Capitalisation of the obtained } \\
\text { product }\end{array}$ \\
\hline $\begin{array}{l}\text { - captures landfill gas or sewer gas } \\
\text { - obtains biogas from the } \\
\text { neutralization and disposal of } \\
\text { organic waste resulting from its } \\
\text { basic activity } \\
\text { - obtains biogas from the } \\
\text { neutralization and disposal of } \\
\text { organic waste from a customer's } \\
\text { activity } \\
\text { - purchases silage/ energy plants } \\
\text { used as substrate } \\
\text { - cultivates silage/ energy plants to } \\
\text { use as substrate }\end{array}$ & $\begin{array}{l}\text { - stores biogas in order to } \\
\text { subsequently convert it into } \\
\text { electric power to balance the } \\
\text { energy grid } \\
\text { - stores biogas as compressed } \\
\text { natural gas (CNG) } \\
\text { - converts biogas into thermal } \\
\text { energy } \\
\text { - converts biogas into electric } \\
\text { power and heat by cogeneration } \\
\text { - converts biogas into electric } \\
\text { power }\end{array}$ & $\begin{array}{l}\text { - feeds biogas into a natural gas network } \\
\text { - uses electric power and/or heat } \\
\text { produced for its own purposes } \\
\text { - sells the energy produced } \\
\text { - to the regional energy operator } \\
\text { - to a district heating company } \\
\text { - on a market/by bilateral contracts } \\
\text { - is the beneficiary of a support scheme } \\
\text { with green certificates } \\
\text { - uses certificates to compensate its own } \\
\text { acquisition obligations } \\
\text { - sells certificates on a market / bilateral } \\
\text { contracts }\end{array}$ \\
\hline
\end{tabular}

PICBE $\mid 214$

Figure 5. Business model options of a biogas plant operator

Source: ibid.

We note that the main sources cited by the study participants regarding the substrate used for biogas plants already implemented are silage and energy plants purchased from third parties or from own production, respectively organic waste from third parties.

The transformation of energy is done predominantly to electric energy, which can be transported and transformed without major losses. At the same time, electric power benefited from the most attractive support scheme, which economically justified investments in renewable energy technologies that have not yet reached the "grid parity" threshold. Cogeneration of electric and thermal energy has also been encouraged by the support schemes implemented and allows for higher conversion efficiency levels than simple electric power generation. For biogas-based energy companies, this is a preferred transformation method according to the perception of eight of the nine experts surveyed active in the biogas sector.

In order to perform a comparative analysis, we have questioned experts and also extracted the results obtained in the study regarding the particularities of other subsectors in renewables, which have experienced a more accelerated development in Romania. Regarding the capitalisation of the goods obtained from the transformation process, we notice quite large differences between the biogas sector and the other renewable sources. The differences are primarily due to the size of the projects - biogas projects have on average an installed capacity far below the projects on other energy sources, which makes the biogas energy producer more likely to use the energy obtained to cover his own needs than in the case of the other sources (66\% vs. $28 \%)$. It should be outlined that the responses given by the experts are especially based on experience from other markets. Preferred customers for both renewable and biogas power producers are network operators who are regular customers in FIT \& FIP schemes and energy dealers. In the case 
of the other renewable energy sectors, the participants did not have an explicit preference in this respect, in the case of biogas, the network operator is preferred by $78 \%$ of the participants while 33\% prefer to deal with energy trading companies. This preference is given by the desire to simplify procedures and the experience of participants with feed-intariff support systems.

Looking at governan ce structures, we note that owners of renewable energy power plants are in most cases individual investors or groups of investors. According to the surveyed experts, the business owner most often identifies with the investor and the plant operator in the biogas business models in use today. Based on the results, biogas plays a more important role in producing electricity to cover own energy needs $(22 \%$ in biogas vs. $4 \%$ for all interviewed experts). Fig. 6 shows the developments suggested by experts in terms of business governance in the biogas and renewable energy business.

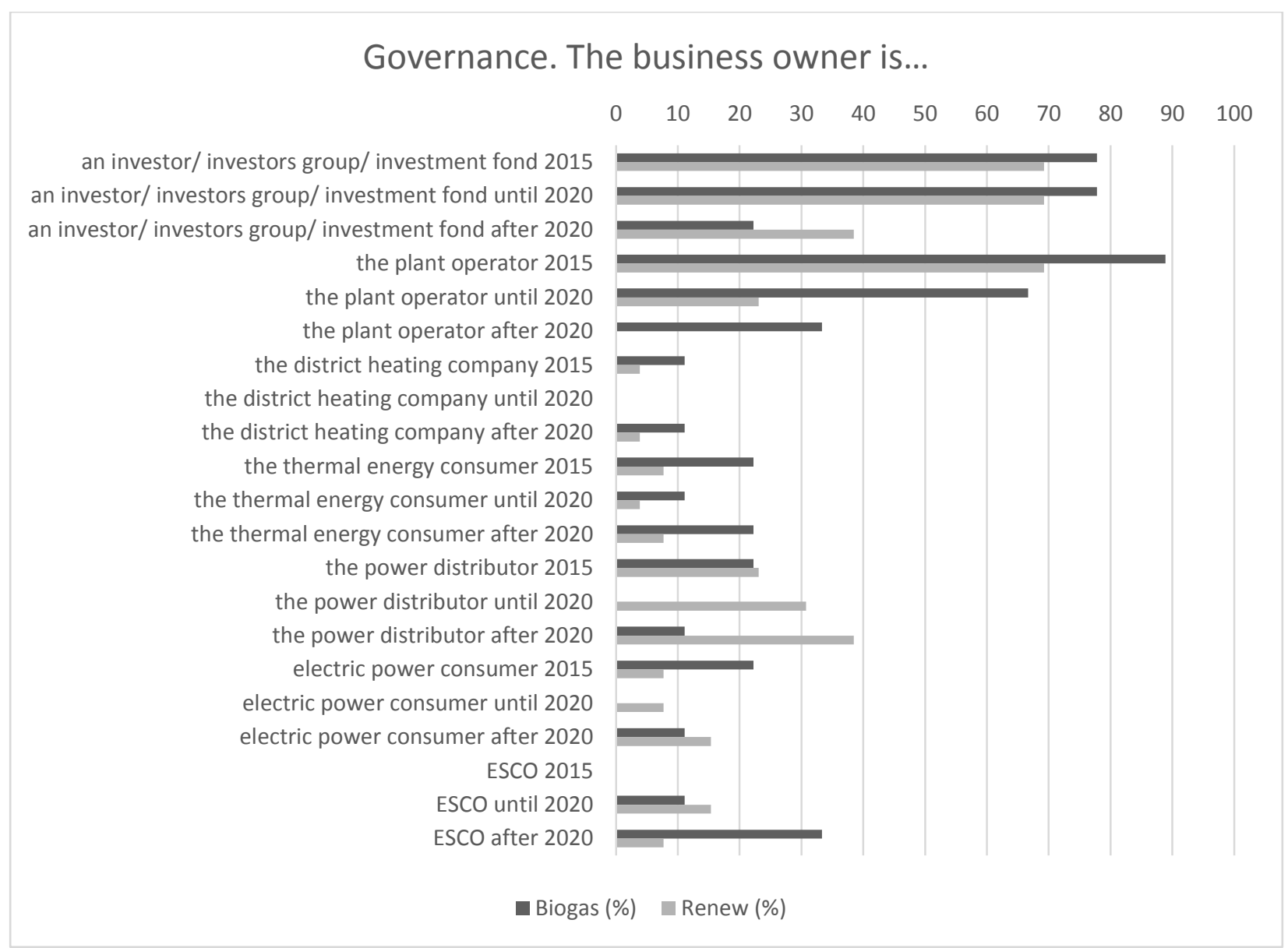

Figure 6. The owners of future power plants (until 2020 and after 2020)

Source: ibid.

Regarding the development of energy capturing, in Fig 7 is presented the trend of changing entrepreneurial models among biogas companies. 


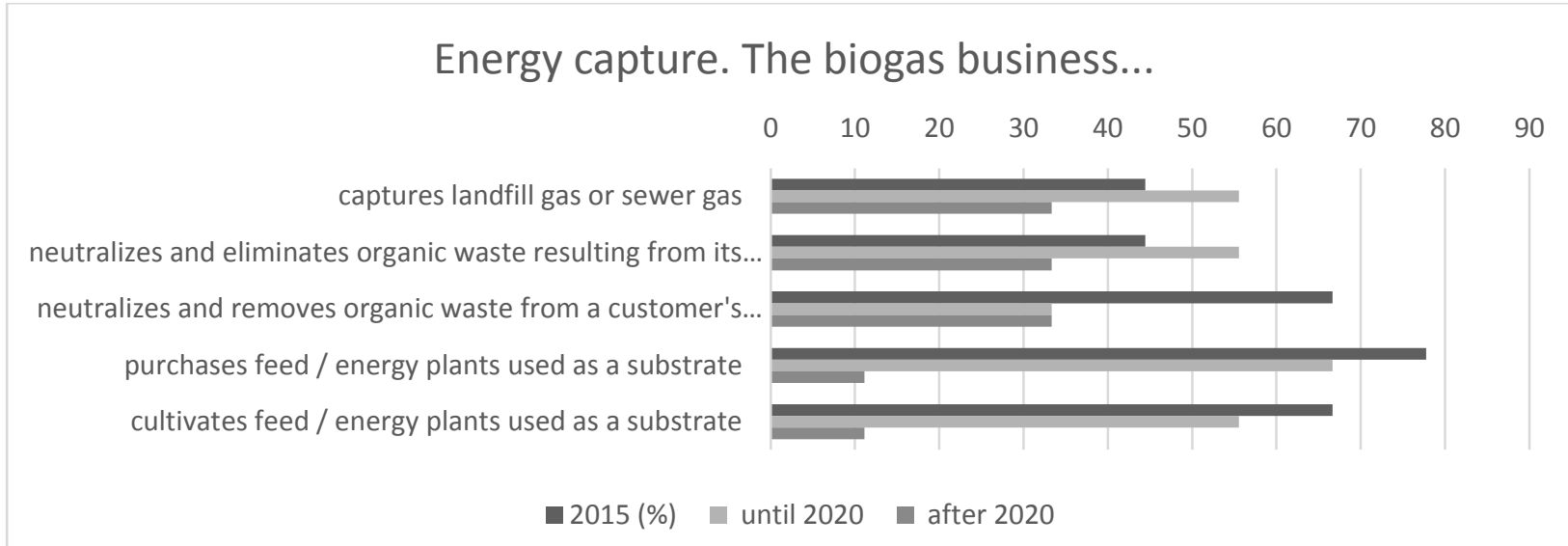

PICBE $\mid 216$

Figure 7. Development of biogas business models - Energy capture

Source: ibid.

We note that in the near future, the importance of gas from landfills and sewage plants and of gas resulting from the neutralisation and disposal of own organic waste will increase, while purchasing or cultivating silage or energy plants will decrease. Although trends emerging from the frequency of designations of different biogas sources do not indicate this, the role of neutralizing organic waste of its own activity or from a customer (partially with ESCO like contracts) has been explicitly highlighted by many of the interviewed experts as an element to be found in business models implemented in the future.

Going a step further, for now, biogas is mainly converted to electric power and thermal energy through cogeneration. This feature of the business model will lose importance, while the use of biogas for heat generation will gain ground. Electric power is introduced into the regional network and is (as well as green certificates are) preferably sold to a network operator. In the future, trading companies will play a more important role, with the experts participating in the study anticipating the gradual increase in the role they play in the market, as shown by Fig. 8. 
Transforming \& Capitalising Energy. The plant biogas business

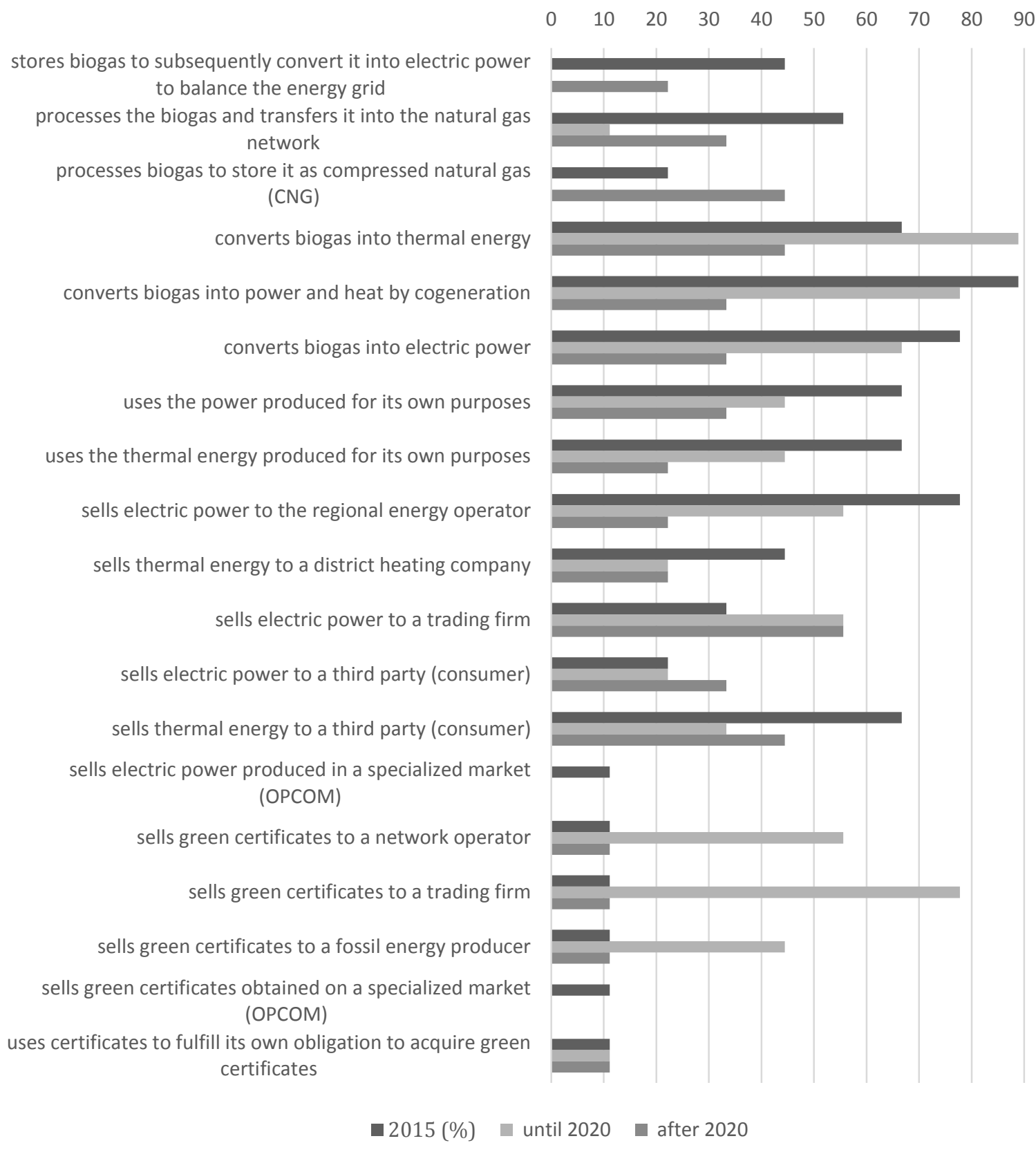

\section{Figure 8. Evolution of Business Models in the Renewable Energy Sector - Transforming \& Capitalising Biogas}

Source: ibid.

When analysing the options of all survey experts, they expect, by 2020 and beyond, a transition to decentralised energy supply. Owners of biogas plants in the future - still mainly investors or groups of investors - will act as local energy suppliers. 
As far as project financing is concerned, Fig. 9 presents the options indicated by experts in this study.

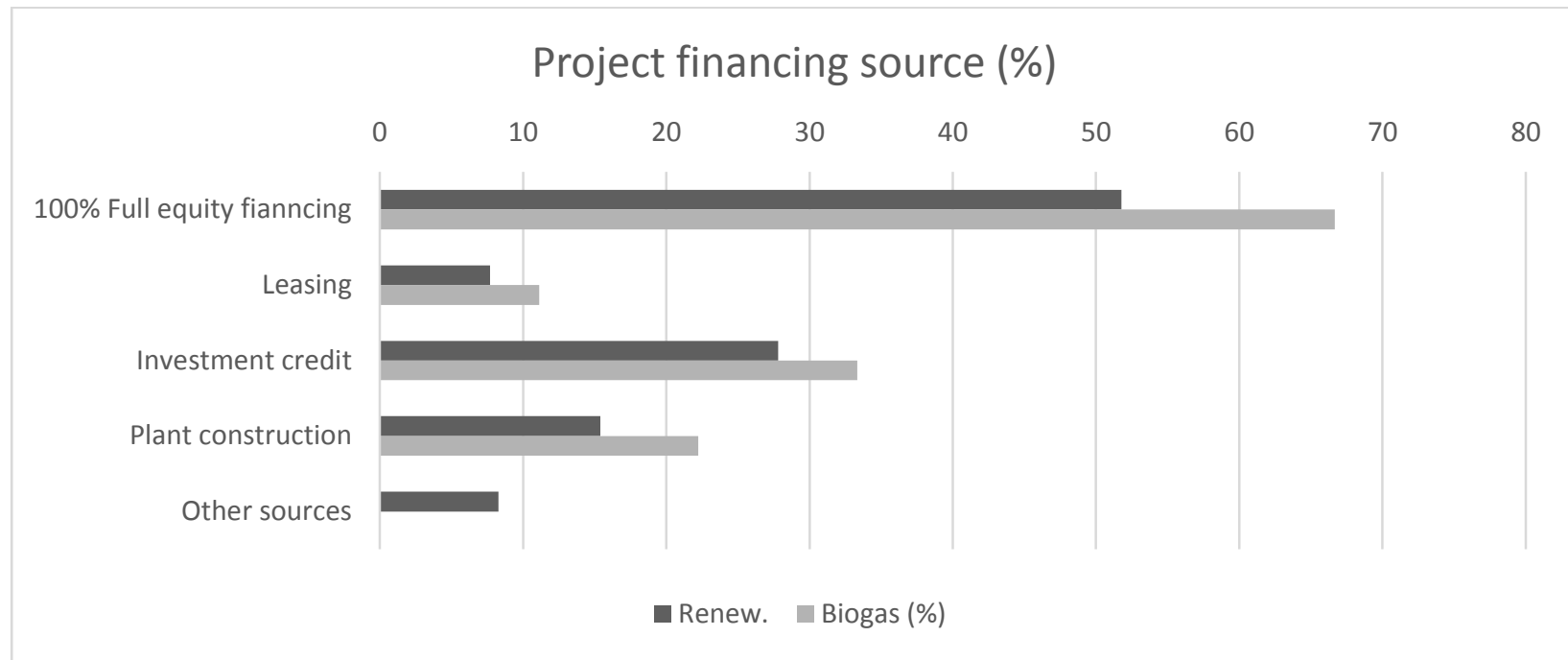

Figure 9. Financing sources for renewable projects

Source: ibid.

We note that business models in the biogas sector mostly use full equity financing (67\%), while for other renewable power plants the incidence of this type of financing, characteristic of entrepreneurial models, is lower, stressing capital lending.

Experts were also interviewed on the key elements of the business models deployed or under implementation. Fig 10 presents expert appointments of business model components considered to be critical to the success of businesses in the renewable energy field.

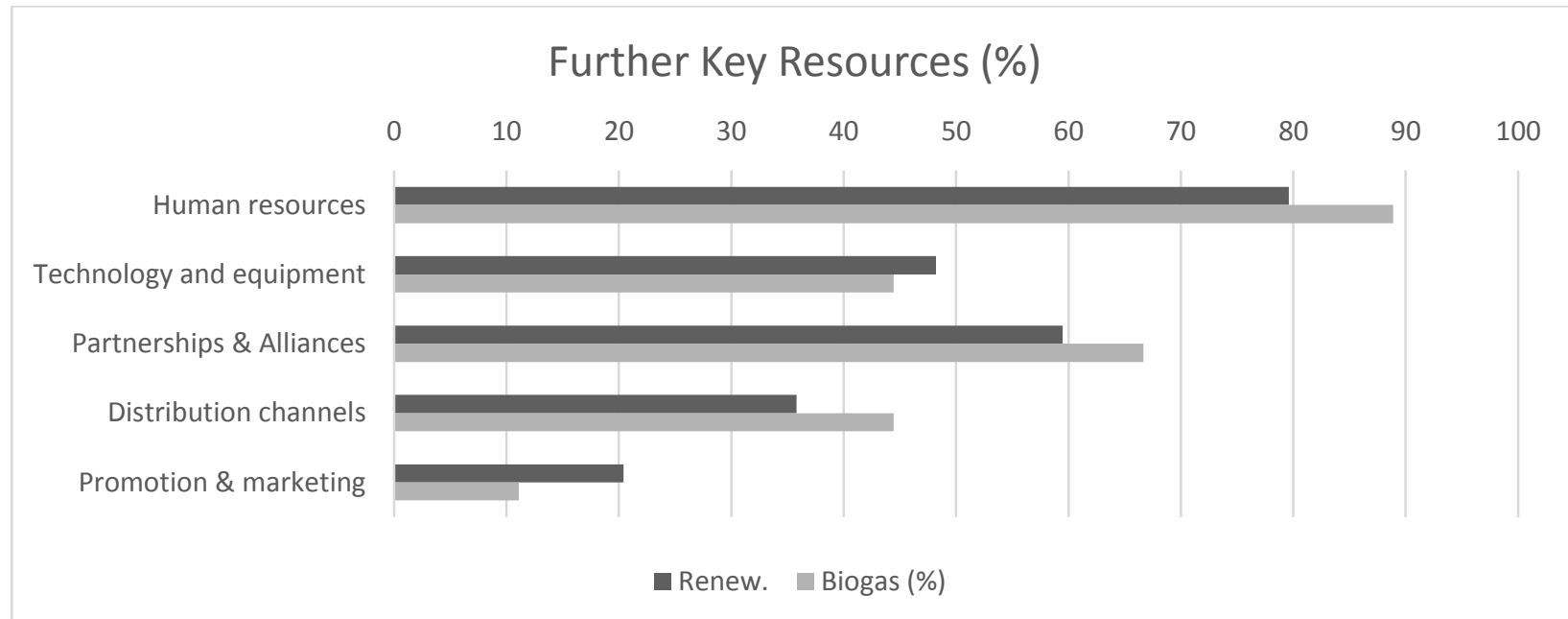

Fig ure10. Key BM elements indicated by experts

Source: ibid.

DOI: 10.2478/picbe-2018-0020, pp. 209-228, ISSN 2558-9652| Proceedings of the $12^{\text {th }}$ International Conference on Business Excellence 2018 
Human resources are the main component of a business in the renewable energy sector indicated by the 26 experts participating in the study followed by partnerships and strategic alliances and technology. According to interviewed experts, the sector does not grow at the potential pace due to the lack of experienced staff and the financing problems that are characteristic of the field.

Experts who have indicated strategic partnerships as indispensable in their business models also emphasize the importance of international cooperation. Representatives of Romanian companies have expressed the need for external partners, while representatives of foreign firms emphasize the need for domestic partners to carry out their projects.

Also, an expert in the solar sector indicates the need for new technologies to ensure greater efficiency as a major factor in influencing the cost-effectiveness of renewable energy projects. Paradoxically, although $77 \%$ of biogas experts are technology providers, they have given technology a less important role than wind industry experts, of which only $14 \%$ come from technology vendors. However, one of the experts in the biogas sector explains that innovative technologies make the difference. In the biogas sector, there is a strong tendency for business models to migrate to the "waste-to-energy" field, a development that depends on new technologies for pretreatment of waste that will be used energetically.

Biogas experts also stress to a great extent the importance attributed to the distribution channels. Technology providers usually work with local staff and distribution companies that also provide facility maintenance and after-sales services. Having an intense maintenance schedule, the operation costs of a biogas plant would increase exponentially in the absence of local service providers that can serve the unit in due time at acceptable costs.

Valuing the products obtained involves tight partnerships at least in relation to the potential heat generated. Thermal energy does not enjoy the same transport facility as electricity, so the heat consumer needs to be in the geographical proximity of the plant and therefore only users within a radius of hundreds of meters from the power plant could count. The final product (electrical power, thermal energy, green certificates) being homogeneous and undifferentiated, promotion strategies and marketing are given less importance, however two of the experts participating in the study emphasize their role especially in collaboration with other partners, "name and market position create confidence in the relationship with partners".

As with regard to decisions on the partnership governance, most experts point to a preference for strategic alliances. The frequency of preference for joint venture partnerships and also for company acquisitions is much higher in other renewable energy sectors. Fig 11 shows the preferences expressed by the 26 experts participating in the study. 


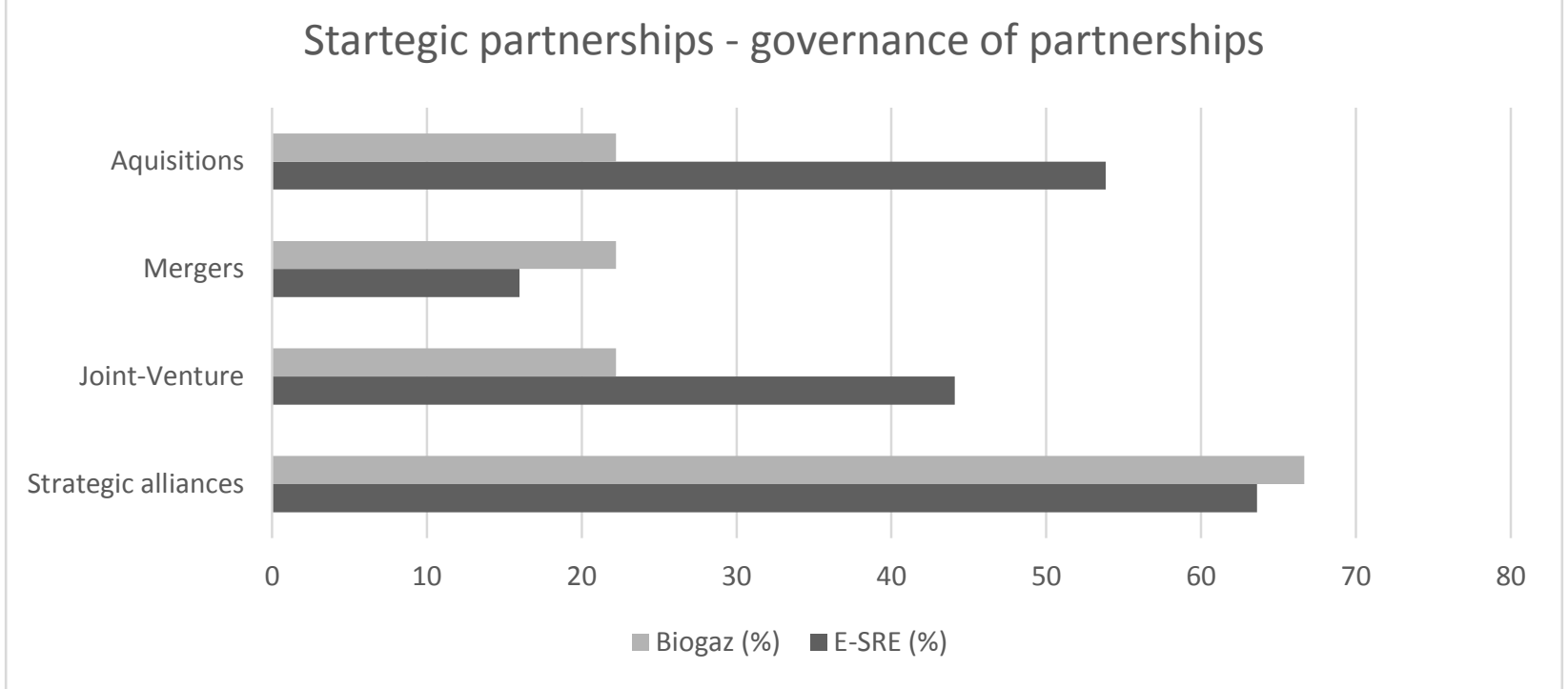

PICBE $\mid 220$

Figure 11. Strategic Partnerships as indicated by the 26 interviewed experts

Source: ibid.

Experts in the study were asked to assess the main advantages of the implemented business model compared to their competition. The question was open, so the results obtained vary greatly.

A large number of experts have addressed elements of governance and strategic decisions. Some experts have listed "focus on key competencies and outsourcing of others", "limited product specialisation", "clear and compact product portfolio", "standardised full solutions" and "focus on a limited number of markets" as the defining features of the implemented business models, other experts listed, on the contrary, the "integration of the whole energy sector specific value chain", "complete design and project management services" or "technological and geographical diversification" as their differentiation points from competition. In terms of internal organisation, the study participants listed "small business organisation for business development - quick decisions, quick responses" and "implementation of LEAN structures" as contributing to the success of their models. Eight of the study participants consider that simpler procedures give them a competitive edge over other bidders on the market.

Turning our attention to the external organisation, we again see the major role assigned to partnerships in this sector. Experts have explicitly called "flexibility and collaboration with a large number of traditional suppliers", "close collaboration with suppliers" and "local partnerships" as defining the success of their work. Experts also highlighted the role of tight "intimacy" with loyal customers and the need for "security" of customers.

We also note from experts' replies that staff and experience play a very important role in business models in the renewable energy sector, specific to entrepreneurial models. Thus, the experts listed "highly specialised employees", "specialised personnel and dynamic management", "skilled staff", "experience over 20 years in the field", "use of experience in 
other markets", "long-term experience" as elements of differentiation of their business models.

With regard to the value proposition, study participants have called "technical, legislative and business knowledge", "German know-how" and "sound market knowledge", "comprehensive technical and financial advice" and "specialised equipment" as the unique selling proposition of the companies they represent.

Study participants also called "performance" and "excellence in operation" the quality of services and products, lower production costs and lower delivery times as elements that differentiate them from competitors. Also with regard to the value proposition, 17 of the 26 experts consider that their competitive advantage is due to the superior features of the products / services they offer. It should be noted that only 2 out of 26 experts responded positively to an explicit question regarding possible lower costs and in the case of better delivery times and conditions 7 out of 26.

\section{The entrepreneurial model within the renewable energy sector}

In order to achieve the goal of Developing a Generic Entrepreneurship Model for the Renewable Energy Sector, we formulated the Hypothesis "The Renewable Energy Sector requires distinct key features of the entrepreneurial model that are different from those of other sectors." Based on our research, we found that four of the five elements determined for entrepreneurial models in other sectors are also considered decisive for entrepreneurial models in the renewable energy sector. Figure 12 shows the key elements of the entrepreneurial models previously identified (Clodnițchi, 2017b) while Figure 13 shows the entrepreneurial model adapted to the specificity of the renewable energy sector.

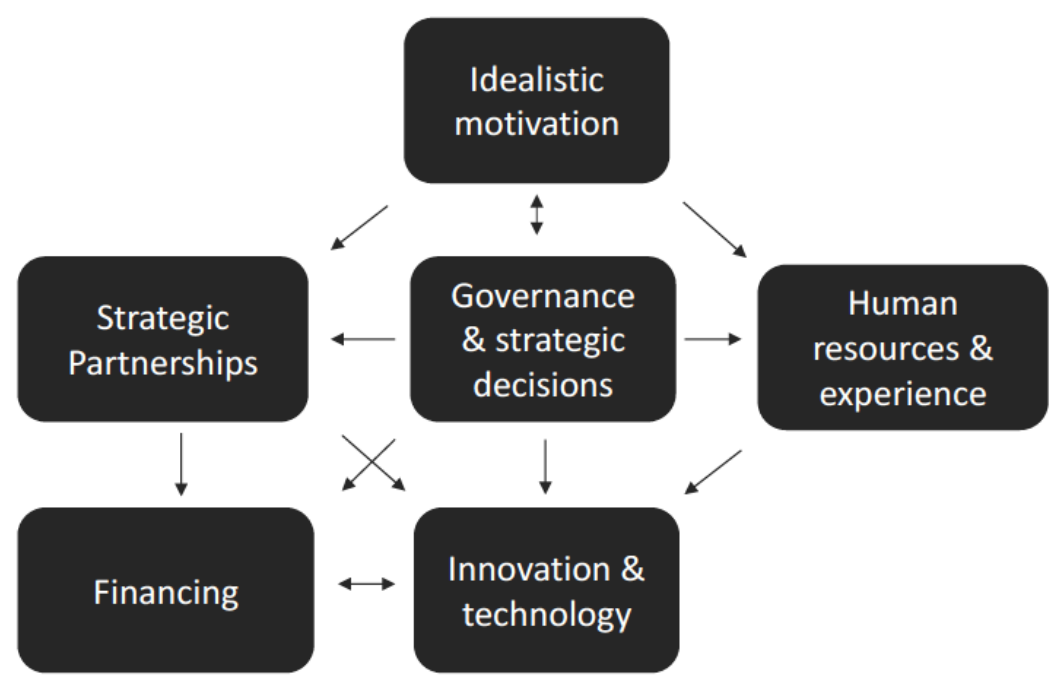

Figure 12. Key elements of entrepreneurial models

Source: Clodnițchi, 2017b. 


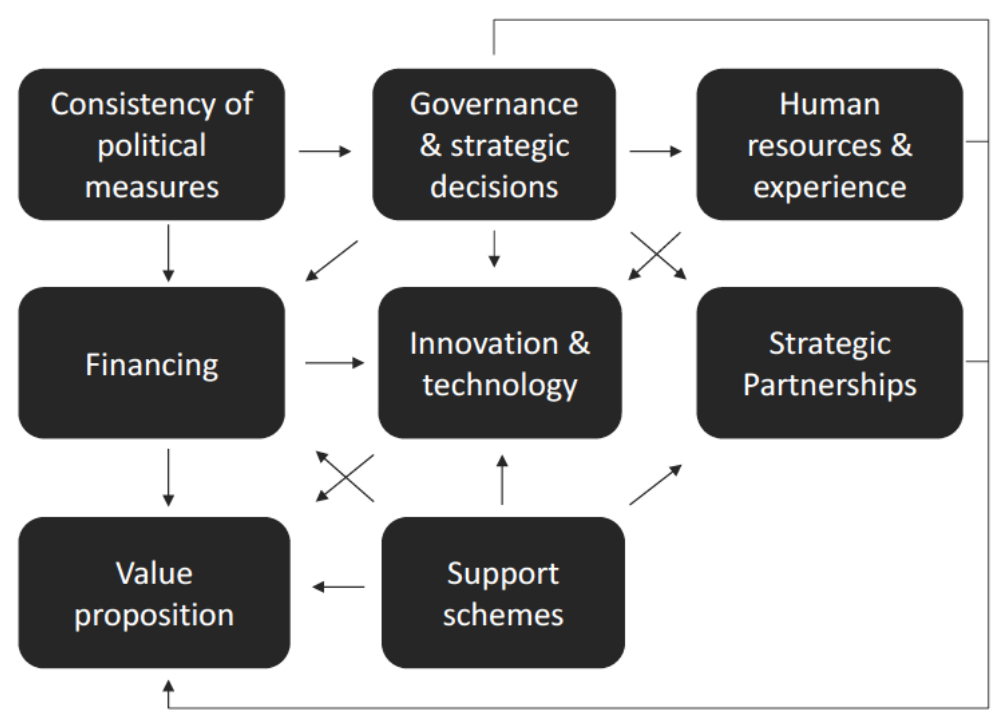

Figure 13. Key elements of entrepreneurial models in the renewable energy sector Source: own compilation.

Surprisingly, the social and ecological dimension, which is the cornerstone of the value proposition in the entrepreneurial models presented by the literature and which is given great importance in the success of the entrepreneurial models implemented in other analysed sectors, was completely neglected by the participants in the study undertaken.

The polarisation of ecological themes being relatively low in Romania, companies are not directly encouraged to "act green". The legal framework on environmental issues is still under construction and the application of legal provisions is currently less developed in Romania than in other EU countries.

Another major difference from entrepreneurial models in other sectors is given by the financing element and the capital flows. In the renewable energy sector, revenue streams and funding are strictly seen in relation to the existing and future legislation on incentives. Thus, these become independent elements, determining the applied entrepreneurship model.

Therefore, we can consider that the formulated hypothesis is confirmed.

\section{Cost structure and revenue streams as part of the entrepreneurial model in the biogas sector}

In Figure 14 is presented a revenue and expenditure structure in an entrepreneurial model in the biogas sector where the substrate is available, so it is applicable to the recovery landfill and sewer gas. 


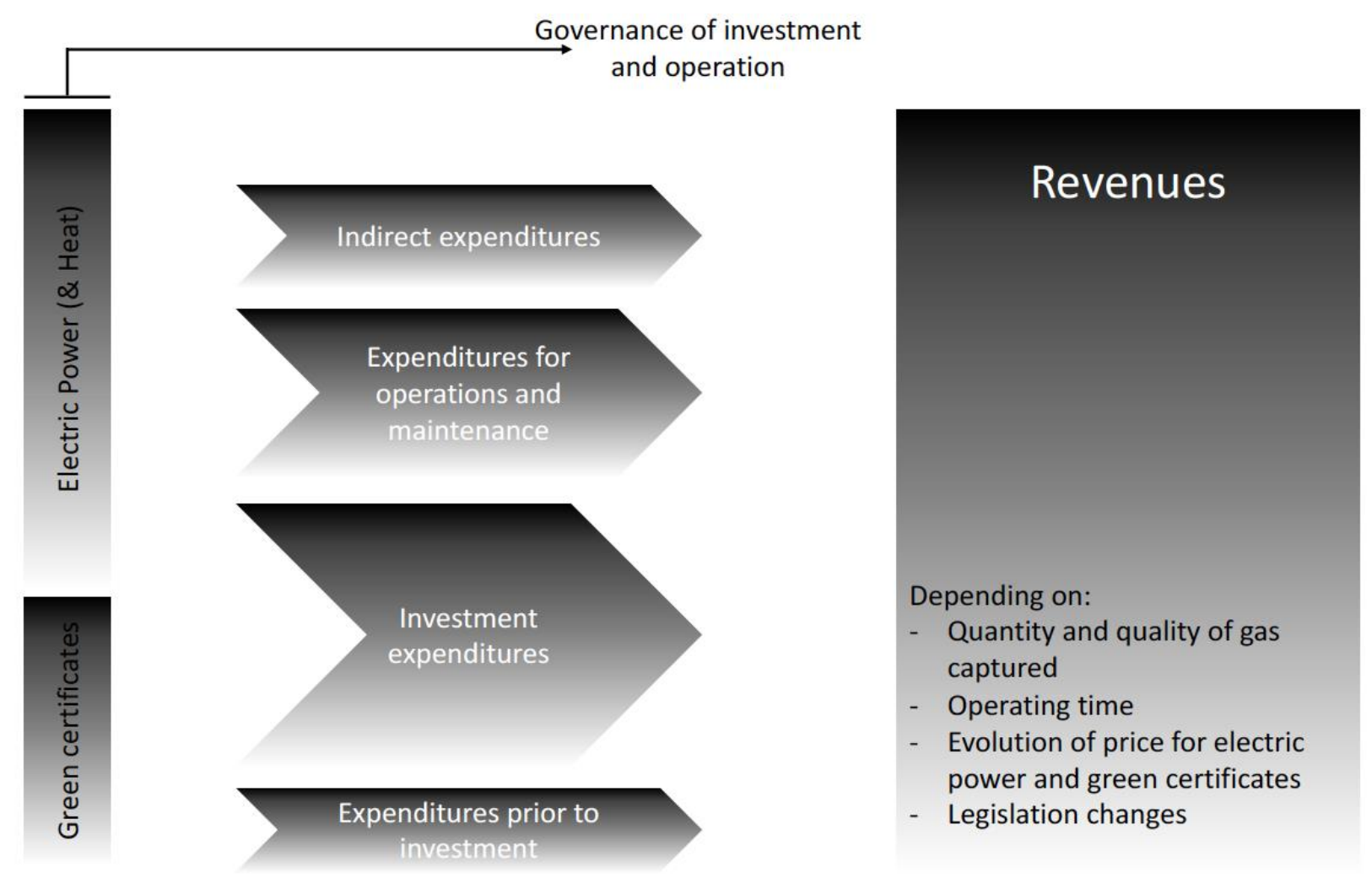

PICBE | 223

Figure 14. Cost Structure and Revenue Streams of a biogas plant working with landfill or sewer gas

Source: own compilation based on revenue model of Haase Energietechnik GmbH.

In the case of agricultural biogas plants, additional costs for substrates, their transport and storage occur. Figure 15 shows an income and expense model of an "agricultural" biogas plant. 


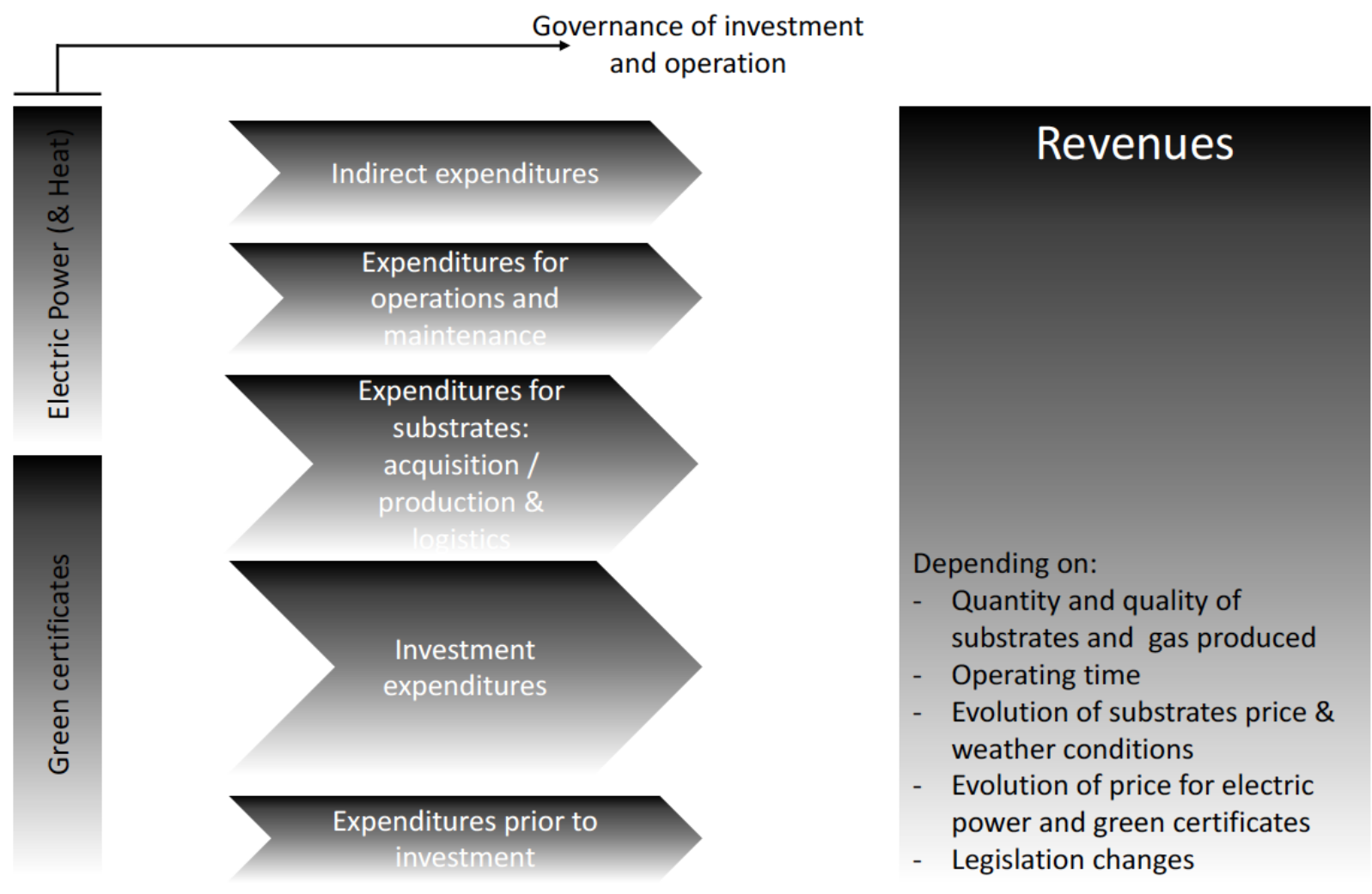

PICBE | 224

Figure 15. Cost Structure and Revenue Streams of a biogas plant working with agricultural substrates

Source: ibid.

These facilities not only depend heavily on agricultural and energy price developments, but depend more on the legislative environment and on the support schemes in operation, because in the income structure of these operators the green certificates component occupies a more important role.

Therefore, it is necessary to extend the entrepreneurial model of the renewable energy sector to the "substrate" key resource, with a clear interdependence between strategic partnerships and substrates, as shown in Figure 16. 


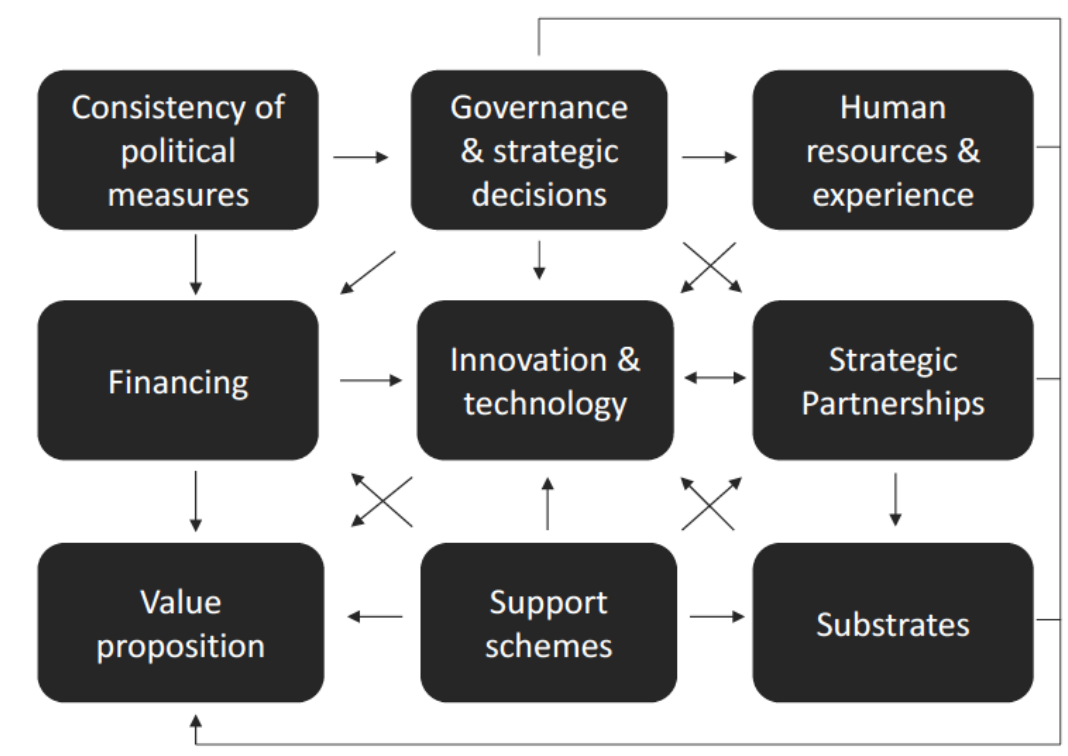

PICBE | 225

Figure 16. Key elements of entrepreneurial models in the biogas sector

Source: own compilation.

\section{Conclusions}

Within this paper we have analysed the business models and the entrepreneurial models implemented in the field of renewable energy paying attention to the specific case of the biogas sector. Examining the characteristics of the business models implemented by the experts consulted, we noticed that they do not fully coincide with the characteristics of the successful entrepreneurial models in other areas presented by the literature. In the following, we will present both, the elements specific to the entrepreneurial models identified as defining the renewable energy and biogas sector as well as those common to other sectors while highlighting their relevance in this sector.

Until the cost for renewable electric power reaches grid parity, the evolution of companies, the sector and the markets for renewable energy is determined by the subsidy schemes and implicitly by political interests and decisions in different geographical areas (territorial administrative units, national states, cross-border unions).

The targeted capture or production of biogas, such as it is in use today, is new or still non-existent in most of the world's countries. In Romania, there is currently an installed capacity of less than $20 \mathrm{MW}$. The slow and quasi-stagnant development of the biogas sector is largely based, according to the interviewed experts, on the amendments to the renewables support legislation - although they have affected the biogas sector less than other sectors.

The determinant role of the political factor was visibly outlined. This, through the proposed regulatory measures and support schemes and the predictability of its actions, is now decisive for the success or failure of a business in the renewable energy sector.

As far as innovation, technology and financing is concerned, companies that have invested in renewable energy prefer, mature technologies that have return characteristics comparable to conventional ones or are about to reach them. This is the pursuit for 
decoupling from the political factor. By this they are tackling two of the three most important factors taken into account by banks when screening potential borrowers (Dima \& Vasilache, 2016): strength of financial statements and the guarantees pledged.

Changes in the external environment over the past 5 years are already reflected in business models of companies as well as in the trends anticipated by sector experts. In the future, the biogas sector is expected to be closely linked to the need to neutralise waste. Introducing a feed-in tariff more than the green certificate support system that was in place should contribute to more entrepreneurial actions in this area, especially those involved in other main areas of activity. Experts predict the development of decentralised energy supply models.

From the point of view of biogas conversion, it is predicted to be used in installations for the simultaneous production of high-efficiency electric power and heat (cogeneration), which for a long while benefited from a more favourable support scheme. In the short and medium term, organic waste collected, treated and stored in ecological landfills or previously unused gas from wastewater treatment plants will certainly be used for energy purposes.

Future technological development, as for instance the use of biogas in fuel cells, could lead to new long-term business models.

Another key element of entrepreneurial models - strategic partnerships - also opens new perspectives for the biogas sector. Despite the low yields in Romanian agriculture and the large fragmentation of farms and livestock farming, Romania has a high natural potential for biogas production. In addition to raw material available in agriculture and animal husbandry, industrial waste from the food industry, municipal waste from landfills and sewage sludge plants that gather generous amounts of organic waste should be considered as important resources in biogas production.

In the transformation phase, biogas can be exploited in cogeneration plants that require strategic partnerships with heat consumers - otherwise the generated heat has to be neutralised and generates additional operating costs for the operator and ecologic damage. According to the experts consulted, investing in cogeneration units, although leading in the past to additional benefits (an additional green certificate per $\mathrm{MWh}$ ), is not profitable if the thermal energy generated remains unused. In some cases, such as the food industry, the heat consumer can also become a biodegradable material supplier.

Another element of differentiation between the models presented in the literature and those implemented in practice is the value proposition. While literature describes predominantly entrepreneurial models generating societal added value for all stakeholders, renewable energy businesses, although inherently adding social added value through their contribution to ecology, are motivated almost exclusively financially.

The results of this study highlighted, among other things, the major role played by human resources and experience in this sector. Many of the analysed projects are experiencing difficulties due to the lack of experienced staff. Considering the need for investment, human and know-how capital, and also the lack of idealistic motivation facing the sector and the population in general, we can estimate that the biogas sector in Romania will continue to grow at a slow pace, independent of the evolution of the legal support 
framework for the sector. A faster pace requires a period of adaptation of the financial and mentality efforts of energy producers, suppliers and consumers.

The transition from CSR as a PR and marketing tool to CSR as an integral part of the business model and company mission could be a key element for the success of a business in the renewable energy and biogas sector. Additionally, decoupling from the influence of the political factor or at least diminishing it by developing and implementing innovative technologies, by accessing previously unexploited resources, and by concluding internal and external strategic partnerships in which the stakeholder role interacted intentionally. CSR actions to raise awareness and popularise the benefits associated with renewable energy production will contribute in the medium and long term to accelerating the development of the sector.

\section{References}

Clodnitchi, R. (2017a). A Critical Synthesis of Scientific Research on Business Models and Business Model Components, Management and Economics Review, 4(2), 297-307.

Clodnitchi, R. (2017b). Paradigm Shift from "Business Model" to "Entrepreneurial Model", Proceedings of the 11th International Management Conference "The Role of Management in the Economic Paradigm of the XXIst Century", 778-793, November 2nd-4th, 2017, Bucharest, Romania.

Dima, A.M., Vasilache, S. (2016). Credit Risk modeling for Companies Default Prediction using Neural Networks, Journal for Economic Forecasting, Institute for Economic Forecasting, vol. 0(3), 127-143.

Ericsson, K., Nikoleris, A., Nilsson, L.J. (2013). The Biogas Value Chains in the Swedish Region of Skåne. TOP-NEST, Project number RD 2011-42. Nordic Energy Research.

European Commission (2009). Directive 2009/28/EC. On the Promotion of the Use of Energy from Renewable Sources and Amending and Subsequently Repealing Directives 2001/77/EC and 2003/30/EC. OJEU, pp. 16-62. L 140 (23.04.2009).

Karlsson, N.P.E., Hoveskog, M., Halila, F., Mattsson, M. (2018), Early phases of the business model innovation process for sustainability: Addressing the status quo of a Swedish biogas-producing farm cooperative, Journal of Cleaner Production, 172, 2759-2772.

Karlsson, N., Halila, F., Mattsson, M., Hoveskog, M. (2017). Success factors for agricultural biogas production in Sweden: a case study of business model innovation. Journal of Cleaner Production, 142(4), 2925-2934.

Lantz, M., Svensson, M., Bjornsson, L., Borjesson, P. (2007). The prospects for an expansion of biogas systems in Sweden e incentives, barriers and potentials. Energy Policy, 35 (3), 1830-1843.

Larsson, M., Gronkvist, S., Alvfors, P. (2013). Barriers and Drivers for Upgraded Biogas in Sweden, Proceedings ICAE 5th International Conference on Applied Energy 2013, Pretoria, South Africa, 1-4 July, 2013.

Lybaek, R., Christensen, T.B., Kjaer, T. (2013). Governing innovation for sustainable development in the Danish biogas sector - a historical overview and analysis of innovation, Sustainable Development, 21(3), 171-182.

Martin, M. (2015). Potential of biogas expansion in Sweden: identifying the gap between potential studies and producer perspectives, Biofuels, 6(5-6), 233-240.

Negro, S.O., Hekkert, M.P. (2008). Explaining the success of emerging technologies by innovation system functioning: the case of biomass digestion in Germany. Technology Analysis \& Strategic Management, 20(4), 465-482.

Negro, S.O., Hekkert, M.P., Smits, R.E. (2007). Explaining the failure of the Dutch innovation system for biomass digestion. A functional analysis. Energy Policy, 35(2), 925-938. 
Nichifor, M.A. (2015). Sustainable business models for wind and solar energy in Romania", Management \& Marketing. Challenges for the Knowledge Society, Vol. 10, No.1, pp. 52-60, DOI: $10.1515 /$ mmcks-2015-0004

Osterwalder, A., \& Pigneur, Y. (2010). Business Model Generation: A Handbook for Visionaries, Game Changers, and Challengers: Wiley.

Raven, R.P.J.M., Geels, F.W. (2010). Socio-cognitive evolution in niche development: comparative analysis of biogas development in Denmark and The Netherlands (1973-

PICBE | 228 2004). Technovation, 30(2), 87-99.

Sanden, B.A., Hillman, K.M. (2011). A framework for analysis of multi-mode interaction among technologies with examples from the history of alternative transport fuels in Sweden, Research Policy, 40(3), 403-414.

Smyth, B.M., Gallachoir, B.P.O., Korres, N.E., Murphy, J.D. (2010). Can we meet targets for biofuels and renewable energy in transport given the constraints imposed by policy in agriculture and energy? Journal of Cleaner Production, 18(16-17), 1871-1685.

Transelectrica 2018, Centralizator de certificate verzi acordate inclusiv luna 12 anul 2017 http://www.transelectrica.ro/documents/10179/4858640/CV+emise+luna+ianuari e+2017/73f9defd-0af2-447a-97a9-30c02a4f2463.

Vernay, A.-L., Mulder, K.F., Manon Kamp, L., de Bruijn, H. (2013). Exploring the sociotechnical dynamics of systems integration e the case of sewage gas for transport in Stockholm, Sweden, Journal of Cleaner Production, 44, 190-199.

Wilkinson, K.G. (2011). A comparison of the drivers influencing adoption of on-farm anaerobic digestion in Germany and Australia. Biomass Bioenergy, 35(5), 1613-1622. 